\title{
BIAYA KUALITAS, PRODUKTIVITAS DAN KUALITAS PRODUK : SEBUAH KAJIAN LITERATUR
}

\author{
Linda Lores ${ }^{a^{*}}$, Retnawati Siregar ${ }^{a}$ \\ ${ }^{a}$ Fakultas Ekonomi dan Bisnis, Universitas Medan Area
}

Diterima Mei 2019; Disetujui Juni 2019; Dipublikasikan November 2019

\begin{abstract}
Abstrak
Tujuan penelitian ini untuk mengkaji tentang jenis biaya kualitas dan hubungannya dengan produktivitas dan kualitas produk pada perusahaan. Penelitian ini merupakan kajian literatur. Kualitas dapat dikatakan dengan defenisi kepuasan pelanggan sedangkan produktivitas merupakan perbandingan antara output yang dihasilkan dengan input yang digunakan untuk menghasilkan output. Studi ini menunjukkan bahwa biaya kualitas berhubungan langsung dan berdampak pada Produktivitas, dan kualitas produk. Jenis Biaya kualitas yang sangat terkait dengan produktivitas dan kualitas produk adalah biaya yang muncul dengan kegiatan pengendalian diantaranya biaya pencegahan dan penilaian. Biaya kualitas dapat menghasilkan kualitas produk yang tinggi di mulai dari naiknya produktivitas sampai dengan produk akan dihasilkan serta tercipta kepuasan pelanggan. Biaya Kegagalan berbanding terbalik dengan biaya pencegahan dan penilaian terhadap kualitas dan produktivitas. Perusahaan dapat melakukan dengan mengurangi biaya kualitas dan meningkatkan kualitas bagi pelanggan mereka dengan metode yang paling umum diterapkan dengan model pencegahan-penilaian-kegagalan (P-A-F) klasik atau dengan konsep lain dan memanfaatkan teknologi informasi.
\end{abstract}

Kata Kunci : Biaya Kualitas, Produktivitas, Kualitas Produk.

\begin{abstract}
This study aims to examine the types of quality costs and their relationship with product productivity and quality in the companies. This research is a conceptual literature. Quality defines as customer satisfaction while productivity is the ratio between the outputs produced. This study shows the quality costs are directly related and have an impact on productivity, and product quality. Types of quality costs that are closely related to productivity and product quality are costs that arise with control activities including prevention and valuation costs. Cost of quality can produce high quality products ranging from increased productivity to the product will be produced and customer satisfaction is created. The cost of failure is inversely proportional to the cost of prevention and evaluation of quality and productivity. Companies can do this by reducing quality costs and improving quality for their customers with the most commonly applied methods with a classic prevention-assessment-failure (P-A-F) model or with other concepts and utilizing information technology.
\end{abstract}

Keyword: Quality Cost, Productivity, Product Quality

How To Cite: Lores, Linda \& Siregar, Retnawati (2019) Biaya Kualitas, Produktivitas dan Kualitas Produk. Jurnal Akuntansi dan Bisnis: Jurnal Program Studi Akuntansi, 5 (2): 94- 101

* email: $\underline{\text { linda lores@ymail.com }}$

\section{PENDAHULUAN}

Kualitas telah menjadi konsep yang sangat luas. Konsep tidak lagi hanya mengacu pada kualitas produk yang tinggi; itu juga mencakup kualitas dalam hal penyampaian 
layanan, ketepatan waktu, layanan purna jual dan proses produksi itu sendiri, dan ini membutuhkan fokus pada perbaikan berkelanjutan (Tolentino A.L, 2004 ( 13-14 may)) (Acharya, U.H., \& Ray, S., 2000) Produk dan layanan berkualitas dapat disampaikan terbaik ketika semua sistem organisasi yang efisien, efektif dan terfokus pada target yang sama (Beechner, A.B \& Koch, J.E, 1997). Deming juga menyatakan bahwasanya 'konsumen adalah bagian yang terpenting dalam lini produksi, dan itu harus menjadi tujuan kualitas untuk memenuhi kebutuhan konsumen sekarang dan masa depan' (Taylor, BW III \& Russell R.S, 2000). Selama bertahun-tahun, kualitas dan produktivitas telah dilihat sebagai dua indeks penting dari kinerja perusahaan, terutama di industri manufaktur. Namun, mereka selalu diperiksa secara terpisah.

Alasan utama bahwa kualitas dan produktivitas tidak diperiksa secara bersamaan adalah bahwa tujuan manajemen mutu dan manajemen produktivitas secara tradisional dipandang sebagai kontradiktif (Deming,W.E, 1989) (Belcher, J.G, 1987) Penelitian terbaru menunjukkan bahwa kualitas dan produktivitas harus memiliki hubungan yang positif. Kualitas dapat dikatakan kepuasan pelanggan sedangkan produktivitas merupakan perbandingan antara output yang dihasilkan dengan input yang digunakan untuk menghasilkan output. Dan tidak akan lengkap jika tidak memperhitungkan elemen kualitas akun, seperti produk yang ditolak atau berkualitas buruk. Karena peningkatan produktivitas tidak hanya berarti produksi produk atau jasa yang efisien, tetapi juga produk dan jasa yang diperlukan, diminta, dan dibeli oleh pelanggan dan masyarakat luas secara berbeda. Orientasi pelanggan sekarang menjadi pertimbangan utama dan kualitas unggul adalah indikator utama kinerja produktivitas yang baik.

Produktivitas menjadi identik dengan kualitas, para perusahaan akan berpikir bahwa mereka telah membuat produk berkualitas yang baik akan tetapi setelah beberapa waktu terungkap bahwa mereka mengadopsi kualitas sebagai alat manajemen yang meningkatkan kualitas dan produktivitas sekaligus mengurangi biaya dengan menghindari pemborosan. Biaya kualitas atau kualitas biaya dalam arti yang lebih luas adalah biaya yang dikeluarkan oleh suatu organisasi mencapai dan mempertahankan kualitas yang baik serta mengelola kualitas yang buruk di sepanjang garisnya operasi dengan tujuan untuk mencapai tingkat kepuasan pelanggan tertinggi. Biaya analisis kualitas memicu perubahan dan memberikan bukti mengapa perubahan harus dilakukan. Kebutuhan untuk meningkatkan posisi keuangan suatu organisasi secara langsung berkorelasi dengan proses pembuatan kualitasperbaikan. Biaya kualitas yang buruk akan cenderung nol, jika setiap aktivitas dilakukan dengan baik di waktu yang akan datang.

Metode untuk meningkatkan kualitas (tradisional atau modifikasi) dan implikasinya pada tingkat kualitas yang buruk dan produk berkualitas baik dapat menentukan hubungan produktivitas dengan kualitas, apakah peningkatan kualitas meningkatkan atau menurunkan produktivitas (van der Wiele, Willimas, \& Dale, 2000). Bayangkan Anda seorang eksekutif di perusahaan bedak tabur baby, dan Anda mulai menerima laporan tentang produk Anda yang memiliki bau yang tidak sedap. Pada saat keluhan meningkat, Anda mendengar bahwa beberapa orang juga mengalami mual, muntah, dan sakit perut. Setelah penyelidikan penuh, mereka menentukan bahwa bau tersebut telah dikaitkan dengan keberadaan jumlah jejak 2,4,6-tribromoanisole (TBA), produk sampingan dari bahan kimia yang digunakan untuk merawat palet kayu yang mengangkut dan menyimpan kemasan. Maka akan terjadi penarikan penuh Tylenol, lebih dari \$ 650 juta dalam pendapatan yang hilang, penurunan $29 \%$ dalam penjualan, penutupan pabrik, pemecatan karyawan, hilangnya pangsa pasar kepada pesaing, dan hit tak ternilai untuk citra merek. Singkatnya, ini adalah biaya kualitas yang buruk. 
Istilah "biaya kualitas" memiliki arti berbeda untuk kasus yang berbeda. Beberapa kasus menganggap biaya dengan kualitas buruk sebagai tindakan menemukan dan memperbaiki pekerjaan yang salah. Yang lain memikirkan biaya untuk mencapai kualitas yang baik. Kedua definisi ini akurat. Penting untuk memahami bahwa biaya kualitas dihasilkan tidak hanya dari memproduksi dan memperbaiki cacat tetapi juga memastikan bahwa produk yang baik dibuat sejak awal. (Giakatis et al,2001). menyatakan bahwa biaya kualitas berkisar antara 5 hingga 30\% dari penjualan. Kent (2005) menyatakan bahwa biaya kualitas total adalah 5-15\% dari omset. Tingginya proporsi biaya kualitas dalam struktur biaya perusahaan keseluruhan memastikan bahwa quantifikasi biaya kualitas tidak dapat diabaikan dan membutuhkan pendekatan interdisipliner. Total biaya keselamatan dan kompensasi tenaga kerja keselamatan secara umum, terlepas dari sifat dan kualitas keselamatan manusia- sistem manajemen, dapat mempengaruhi produktivitas, kualitas dan kuantitas produksi ( (Gholamabbas Shirali, Reza Savari, Kambiz Ahmadiangali, and Vahid Salehi, 2017). Makalah ini melihat lebih dalam pada banyak biaya yang terkait dengan kualitas, produktivitas dan menyoroti berbagai metode dan praktik terbaik untuk memastikan kualitas yang baik.

\section{Produktivitas}

Pengukuran produktivitas dengan membagi output dengan input tidak lengkap jika tidak memperhitungkan elemen kualitas akun, seperti produk yang ditolak atau berkualitas buruk. Karena peningkatan produktivitas tidak hanya berarti produksi produk atau jasa yang efisien, tetapi juga produk dan jasa yang diperlukan, diminta, dan dibeli oleh pelanggan dan masyarakat luas secara berbeda. Orientasi pelanggan sekarang menjadi pertimbangan utama dan kualitas unggul adalah indikator utama kinerja produktivitas yang baik. Produktivitas menjadi identik dengan kualitas produk . Pada saat yang sama, kualitas juga menjadi konsep yang jauh lebih luas.

\section{Biaya Kualitas}

Biaya kualitas sebagai biaya yang terkait dengan pencegahan, identifikasi dan peningkatan produk berkualitas rendah bersamaan dengan biaya peluang yang timbul dari hilangnya waktu produksi dan penjualan sebagai akibat dari kualitas rendah. Biaya kualitas adalah biaya yang dikeluarkan atau kemungkinan terjadi karena kualitas yang buruk. Biaya kualitas terkait dengan pembuatan, identifikasi, perbaikan dan pencegahan kerusakan. Yang merupakan total biaya kualitas termasuk biaya kualitas yang dikeluarkan untuk meningkatkan kesadaran akan kebutuhan menghindari kesalahan sehingga tidak ada pemborosan atau biaya yang dikeluarkan karena kesalahan produk perlu diperbaiki. Untuk lebih jelas, dapat dilihat pada Tabel 1 dibawah mengenai Kategori Utama Biaya Kualitas (Quality Cost) beserta contoh biaya-biaya yang akan timbul dari Biaya Kualitas tersebut.

Tabel 1 Kategori dan Contoh Biaya kualitas

\begin{tabular}{|ll|}
\hline \hline \multicolumn{1}{|c|}{ Kategori } & \multicolumn{1}{c|}{ Contoh biaya yang perlu dikeluarkan } \\
\hline \hline Biaya Pencegahan & 1. Biaya Pelatihan (Training Cost) \\
(Preventive Cost) & 2. Proses Capability Studies (Penelitian Kapabilitas Proses) \\
& 3. Vendor Survey \\
& 4. Quality Planning and Design \\
\hline \hline & 1. Segala Jenis Pengujian (testing) dan Inspeksi \\
Biaya Penilaian & 2. Pembelian Peralatan Pengujian dan Inspeksi \\
(Appraisal Cost) & 3. Peninjauan Kualitas dan Audit (Quality Audit and \\
& Review) \\
\hline \hline
\end{tabular}




\begin{tabular}{|ll|}
\hline \hline & 4. Biaya Laboratorium \\
\hline \hline Biaya Kegagalan & 1. Biaya Scrap dan pengerjaan ulang (Rework) \\
(Failure Cost) Internal & $\begin{array}{l}\text { 2. Biaya Perubahan Desain (Design Change) } \\
\text { 3. Biaya Kelebihan Persedian (Excess Inventory Cost) } \\
\text { 4. Biaya Pembelian Bahan }\end{array}$ \\
\hline \hline Biaya Kegagalan & 1. Biaya Purna Jual / Jaminan (Warranty) \\
(Failure Cost) Eksternal & 2. Biaya Pengembalian Produk (Return and Recall) \\
& 3. Biaya Penangan Keluhan Pelanggan \\
& 4. Biaya Ganti Rugi \\
\hline \hline
\end{tabular}

\section{Kualitas Produk}

Menurut Organisasi Internasional untuk Standardisasi (ISO), kualitas produk didefinisikan sebagai kemampuan untuk memuaskan pelanggan dan pasar ( (Lakhal L, Pasin F., 2008), yaitu sering dipisahkan menjadi delapan dimensi, terdiri dari kinerja, fitur, keandalan, kesesuaian, daya tahan, kemudahan servis, estetika, dan kualitas yang dirasakan. Perusahaan dengan kualitas produk yang lebih tinggi lebih mungkin untuk menangkap nilai pelanggan yang superior, sehingga meningkatkan daya saing mereka sendiri (Kafetzopoulos DP, Psomas EL, Gotzamani KD, 2015) (Prakash A, Jha SK, Prasad KD, Singh AK, 2017) Secara umum, kualitas produk terdiri dari kualitas nyata (kinerja, daya tahan, ukuran, dll.) dan kualitas tidak berwujud (estetika, kemudahan servis, persepsi kualitas). Beberapa metrik digunakan dalam mengukur kualitas nyata, seperti item yang rusak (Chuang C-J, Ho C-H, Ouyang L-Y, Wu C-W, 2013). Kualitas tidak berwujud terutama mengacu pada reputasi perusahaan dan kualitas pelayanan, seperti kemudahan servis pelayanan dan persepsi kualitas (Ojasalo J, 2006).

Hasil penelitian tentang biaya kualitas, kualitas produk dan produktivitas menghasilkan produk yang berkualitas. beberapa hasil riview jurnal sebagai berikut: (Hadi Wahyono, Arnis Budi Susanto, 2017) yang menunjukkan hasil penelitiannya bahwa ada pengaruh kualitas yang signifikan biaya (biaya pencegahan), biaya penilaian dan biaya kegagalan internal) secara bersamaan pada tingkat kerusakan produk dan biaya pencegahan dan biaya penilaian sebagian berpengaruh negatif signifikan pada tingkat kerusakan produk.dan sebagai variabel yang paling berpengaruh adalah biaya pencegahan. (ALI, KHAIRUL W A R MOHD,RUSHAMI ZIEN YUSOFF,zakaria Abas, 2001) menujkukkan hasil penelitian mereka bahwa ditemukan secara signifikan terkait dengan produktivitas dalam manajemen pendapatan dan biaya. Konstruksi untuk fokus karyawan memiliki hubungan positif dengan produktivitas dalam pendapatan dan manajemen biaya sedangkan proses manajemen memiliki hubungan terbalik yang signifikan dengan produktivitas dalam manajemen pendapatan dan biaya.

(Dubravka Pekanov StarĀevip , 2015) dalam penelitiannya yang menunjukkan bahwa perusahaan yang mengukur biaya kualitas mencapai kualitas produk yang lebih tinggi kinerja dan keandalan. Selain itu,ini menunjukkan bahwa karakteristik perusahaan berbeda tergantung pada apakah mereka mengukur kualitasnya biaya atau tidak. Reorganisasi dan kuantifikasi biaya kualitas dapat dibenarkan dengan kemungkinan keuntungan finansial bagi perusahaan. Karena itu, perusahaan harus didorong untuk mengekstraksi biaya kualitas dari total biaya overhead di untuk meningkatkan kualitas dan akibatnya mencapai hasil keuangan yang lebih baik. (Rina Tresnawati,Evi Octavia, Shinta Dewi Herawati, 2017) menemukan bahwa biaya efisiensi dan kualitas secara signifikan mempengaruhi profitabilitas perusahaan yang bersangkutan dengan mengubah biaya pemeliharaan dan perbaikan yang dihasilkan dari kegagalan internal dan eksternal. 
(Sailaja A, P C Basak and K G Viswanadhan, 2015) yang menganalisis spesifikasi produk pelanggan dapat dipenuhi dengan mengikuti langkah-langkah kontrol kualitas dalam proses produksi dan dapat dipastikan dengan biaya yang efektif hanya jika kualitas dari setiap dan setiap proses dalam organisasi didefinisikan dengan baik dan dipastikan tanpa penyimpangan. (Gholamabbas Shirali, Reza Savari,, Kambiz Ahmadiangali, and Vahid Salehi, 2017) menemukan bahwa Total biaya keselamatan dan kompensasi tenaga kerja keselamatan pada umumnya, terlepas dari sifat dan kualitas sistem manajemen keselamatan, dapat berdampak pada produktivitas, kualitas dan kuantitas produksi di samping faktor-faktor produksi lainnya. Tentunya jika program keselamatan ditargetkan dan dikodifikasi, efek investasi akan berlipat ganda.

(Fayza M. Obied-Allah, 2016) penelitiannya menemukan bahwa proporsi bagi hasil yang dialokasikan untuk pemasok meningkat karena biaya daur ulang pemasok meningkat, dan Proporsi pembagian pendapatan yang dialokasikan untuk produsen meningkat sejalan dengan meningkatnya biaya pencegahan dan penilaian. (Basim AlNajjar, 1996) bahwa Teknologi Informasi, sistem-TI mengidentifikasi dan menghilangkan penyimpangan kualitas dan penyebab kegagalan pada tahap awal, dan penggunaan yang luas dari umpan balik data adalah alat yang disarankan untuk mencapai peningkatan berkelanjutan dan untuk memastikan produk-produk berkualitas tinggi.

(Arthur M. Schneiderman, 1986) juga menemukan bahwa biaya kegagalan menurun sementara penilaian ditambah biaya pencegahan meningkat. Pengorbanan nyata ini menunjukkan bahwa ada tingkat kualitas optimal dan bahwa upaya untuk lebih meningkatkan kualitas di atas tingkat ini akan meningkatkan total biaya dan menurunkan kinerja keuangan. (Andrea Schiffauerova, Vince Thomson, 2006) menunjukkan bukti bahwa perusahaan yang mengadopsi konsep CoQ berhasil mengurangi biaya kualitas dan meningkatkan kualitas bagi pelanggan mereka. Survei menunjukkan bahwa metode yang paling umum diterapkan adalah model pencegahanpenilaian-kegagalan (P-A-F) klasik; Namun, model biaya kualitas lainnya digunakan dengan sukses juga

(Vincent K. Omachonu, Sakesun Suthummanon, Norman G. Einspruch, 2004) memperlihatkan hasil penelitian mereka bahwa ada hubungan terbalik antara biaya penilaian ditambah biaya pencegahan dan biaya kegagalan, hubungan antara biaya penilaian ditambah biaya pencegahan dan kualitas adalah positif. Akhirnya, biaya kegagalan berkorelasi negatif dengan kualitas. Hasilnya menunjukkan bahwa ketika biaya penilaian ditambah biaya pencegahan meningkat, kualitas meningkat dan biaya kegagalan menurun, dan (Yu Lin, Biwei Liang, Xuechang Zhu,, 2018) dalam penelitiannya, menunjukkan bahwa kinerja persediaan memiliki dampak positif pada produk kualitas saat menggunakan efisiensi persediaan, produktivitas persediaan dan persediaan kecenderungan untuk mengukur kinerja persediaan. Selanjutnya, pengaruh persediaan pada kualitas produk ditemukan sebagian dimediasi oleh keuangan kinerja. Menemukan bahwasanya kinerja persediaan sebagai anteseden dari kualitas produk. Manajer tanpa likuiditas yang cukup atau keunggulan biaya untuk mendapatkan kinerja keuangan yang lebih baik dapat dicapai

\section{PEMBAHASAN}

\section{Hubungan antara Biaya kualitas terhadap Produktivitas}

Peningkatan produktivitas telah menjadi masalah besar bagi semua industri dan untuk bangsa juga. Tetapi ada begitu banyak tantangan dalam mencapai produktivitas yang lebih tinggi. Kelangkaan sumber daya secara serius mempengaruhi produktivitas 
yang lebih tinggi. Ini akan menjadi ancaman besar bagi negara-negara berkembang dan maju.

Masalahnya adalah konsumsi sumber daya alam yang tidak terkendali seperti pohon, batubara, minyak bumi, bahan bakar fosil, dan lain-lain. Untuk dapat mencegah terjadinya kualitas produk yang rendah akan dibutuhkan suatu biaya yang tidak sedikit jumlahnya. Setiap jumlah rupiah yang dikeluarkan untuk mencegah terjadinya kualitas yang rendah, bukan merupakan tindakan yang merugikan perusahaan melainkan akan dapat menimbulkan keuntungan-keuntungan dalam jangka panjang karena dengan kualitas yang baik. Sehingga produk perusahaan akan semakin dipercaya oleh para konsumennya biaya tersebut dikenal dengan biaya kualitas. Biaya kualitas muncul karena adanya kualitas buruk dan karena adanya tujuan produksi yang berkualitas sebelum sampai ketangaan Konsumen atau pelanggan. Produktivitas merupakan perbandingan input terhadap output dalam menghasilkan produk. Biaya kualitas dapat dibebankan pada saat produk dalam proses produksi dalam kegiatan pengendalian dengan mendeteksi kualitas yang buruk kualitas yang buruk mungkin terjadi dengan biaya yang disebut dengan biaya pencegahan dan penilaian. Menurut (Golamambas et.all 2017) Total biaya keselamatan dan kompensasi tenaga kerja keselamatan pada umumnya, terlepas dari sifat dan kualitas sistem manajemen keselamatan, dapat berdampak pada produktivitas, kualitas dan kuantitas produksi . Menurut (Sailaja et all 2015) Spesifikasi produk pelanggan dapat dipenuhi dengan mengikuti langkah-langkah kontrol kualitas dalam proses produksi dan dapat dipastikan dengan biaya yang efektif hanya jika kualitas dari setiap dan setiap proses dalam organisasi didefinisikan dengan baik dan dipastikan tanpa penyimpangan. Menurut Ali Khairull 2001 , menyatakan hasil penelitiannya ditemukan secara signifikan terkait dengan produktivitas dalam manajemen pendapatan dan biaya. Konstruksi untuk fokus karyawan memiliki hubungan positif dengan produktivitas dalam pendapatan dan manajemen biayaJadi dapat dikatakan biaya kualitas berhubungan langsung dan berdampak pada hasil produksi. Artinya hasil produk tergantung pada proses produksi dalam hal produktivitasnya yang menimbulkan biaya.

\section{Hubungan Biaya Kualitas dengan Kualitas Produk}

Kualitas produk merupakan kemampuan perusahaan untuk memuaskan pelanggan dan pasar. Biaya kualitas yang lebih sering muncul atau ditekankan pada saat barang produk belum sampai ke konsumen atau dipasarkan. Jadi biaya yang dibebankan pada proses penilaian dan proses pencegahan lebih berdampak pada kualitas produk.Menurut Vincet $\mathrm{K}$ et.all 2004 , hasil penelitiannya menyatakan adanya hubungan terbalik antara biaya penilaian ditambah biaya pencegahan dan biaya kegagalan, hubungan antara biaya penilaian ditambah biaya pencegahan dan kualitas produk adalah positif. Akhirnya, biaya kegagalan berkorelasi negatif dengan kualitas. Hasilnya menunjukkan bahwa ketika biaya penilaian ditambah biaya pencegahan meningkat, kualitas meningkat dan biaya kegagalan menurun. Karena biaya penilaian dibebankan untuk menentukan apakah produk atau jasa yang dihasilkan telah sesuai dengan persyaratan atau kebutuhan pelanggan, dapat dicontohkan seperti biaya pemeriksaan, dan pengujian bahan baku, pemeriksaan kemasan , pengawasan kegiatan penilaian, penerimaan produk, penerimaan proses dan peralatan. Menurut Bassim et.all 1996, menyatakan hasil temuannya bahwasanya Teknologi Informasi, sistem-TI. Mengidentifikasi dan 'menghilangkan' penyimpangan kualitas dan penyebab kegagalan pada tahap awal, dan penggunaan yang luas dari umpan balik data adalah alat yang disarankan untuk mencapai peningkatan berkelanjutan dan untuk memastikan produkproduk berkualitas tinggi. Jadi teknologi informasi merupakan salah satu alat yang 
digunakan untuk pengendalian produk yang dihasilkan yang dapat dimasukan bebannya ke dalam biaya pengendalian produk. Dikatakan bahwasanya biaya kualitas berhubungan dan berdampak langsung dengan kualitas produk terutama di jenis biaya kualitas pencegahan dan pengendalian. Sedangkan biaya kegagalan sangat berdampak terutama pendapatan perusahaan karena kehilangan pelanggan akibat produk rusak atau cacat terutama biaya kegagalan eksternal. Sedangkan biaya kegagalan internal dilakukan pada saat produk belum sampai ke pelanggan tetapi sudah di produksi dan biaya ini muncul pada saat proses penilaian produk dilakukan. Menurut Arthur M 1986, menemukan bahwa : biaya kegagalan menurun sementara penilaian ditambah biaya pencegahan meningkat. Pengorbanan nyata ini menunjukkan bahwa ada tingkat kualitas optimal dan bahwa upaya untuk lebih meningkatkan kualitas di atas tingkat ini akan meningkatkan total biaya dan menurunkan kinerja keuangan. Menurut Rina et.all 2017 menyatakan biaya efisiensi dan kualitas secara signifikan mempengaruhi profitabilitas perusahaan yang bersangkutan dengan mengubah biaya pemeliharaan dan perbaikan yang dihasilkan dari kegagalan internal dan eksternal. Menurut (dubravka 2015), menyatakan perusahaan yang mengukur biaya kualitas mencapai kualitas produk yang lebih tinggi kinerja dan keandalan. Artinya kuantifikasi biaya kualitas dapat dibenarkan dengan kemungkinan keuntungan finansial bagi perusahaan. Karena itu, perusahaan harus didorong untuk mengekstraksi biaya kualitas dari total biaya overhead di untuk meningkatkan kualitas dan akibatnya mencapai hasil keuangan yang lebih baik .

\section{SIMPULAN}

Biaya Kualitas berhubungan langsung dan berdampak pada Produktivitas, dan kualitas produk. Jenis Biaya kualitas yang sangat mempengaruhi produktivitas dan kualitas produk adalah biaya yang muncul dengan kegiatan Pengendalian diantaranya biaya pencegahan dan Penilaian.Biaya kualitas dapat menghasilkan kualitas produk yang tinggi yang di mulai dari produktivitas sampai produk dihasilkan dan tercipta kepuasan pelanggan sesuai dengan pengertian kualitas itu sendiri.Biaya Kegagalan berbanding terbalik dengan biaya pencegahan dan penilaian terhadap kualitas dan produktivitas.Perusahaan dapat melakukan dengan mengurangi biaya kualitas dan meningkatkan kualitas bagi pelanggan mereka dengan metode yang paling umum diterapkan dengan model pencegahan-penilaian-kegagalan (P-A-F) klasik; contohnya mengadopsi konsep CoQ berhasil mengurangi biaya kualitas dan meningkatkan kualitas bagi pelanggan mereka atau dengan konsep lain dan memanfaatkan teknologi informasi. Saran dalam review ini adalah penelitian biaya kualitas terhadap kualitas produk dan produktivitas dapat diteliti kembali dengan menambah supply chain sebagai variabel pemoderasi.

\section{DAFTAR PUSTAKA}

Acharya, U.H., \& Ray, S. (2000). ISO 9000 certification in Indian industries: A survey. Journal of Total Quality Management, 11(3), 261-266.

ALI, KHAIRUL W A R MOHD,RUSHAMI ZIEN YUSOFF,zakaria Abas. (2001). The Relationship Between Quality Management Practices and Productivity in Revenue and Cost Management :A Study of Local Authorities in Peninsular Malaysia. Malaysian Management Journal 5 , 35-47.

Andrea Schiffauerova, Vince Thomson. (2006). A Review of Research on Cost of Quality Models and Best Practices. International Journal of Quality \& Reliability Management , 1-23.

Arthur M. Schneiderman. (1986). Optiuim Quality Cost Zero defects: Are they contradictory Concepts? Quality Progress, C1-C4.

Basim Al-Najjar. (1996). Total Quality Maintanence An approach for continuous reduction in costs of quality products. Journal of Quality in Maintenance Engineering, , Vol. 2,Issue: 3, pp 4-20.

Beechner, A.B \& Koch, J.E. (1997). Integritating ISO 0001 and IS014001. Quality Progress , 33-36. 
Belcher, J.G. (1987). Productivity plus +: how today's best run companies are gaining the competitive edge. Houston, TX Gulf Publishing Co .

Chuang C-J, Ho C-H, Ouyang L-Y, Wu C-W. (2013). An Integrated Inventory Model with Order-SizeDependent Trade Credit and Quality Improvement. Procedia Computer Science , 65-72.

Deming,W.E. (1989). out of the crisis. Massachusetts Institute of technology, center forAdvenced Engineering study, 248.

Dubravka Pekanov StarĀevip . (2015). QUANTIFICATION OF QUALITY COSTS:IMPACT ON THE QUALITY OF PRODUCTS. EKONOMSKI PREGLED, , 233-249.

Fayza M. Obied-Allah. (2016). Quality Cost and Its Relationship to Revenue Sharing in Supply Chain. Accounting and Finance Research , 173-189.

Gholamabbas Shirali, Reza Savari, Kambiz Ahmadiangali, and Vahid Salehi. (2017). The Effect of Safety Costs on Productivity and Quality: A Case Study of Five Steel Companies in Ahvaz. Jundishapur J Health Sci, 1-6.

Gholamabbas Shirali, Reza Savari,, Kambiz Ahmadiangali, and Vahid Salehi. (2017). The Effect of Safety Costs on Productivity and Quality: A Case Study of Five Steel Companies in Ahvaz. Jundishapur J Health Sci.

Hadi Wahyono, Arnis Budi Susanto. (2017). The Analysis Of Quality Cost On Level Of Product Damage. INTERNATIONAL JOURNAL OF SCIENTIFIC \& TECHNOLOGY RESEARCH , 118-121.

Kafetzopoulos DP, Psomas EL, Gotzamani KD. (2015). The impact of quality management systems on the performance of manufacturing firms. Journal of Multinational Financial Management vol 18 No.2 , 7993.

Lakhal L, Pasin F. (2008). The direct and indirect impact of product quality on financial performance: A causal model. Total Quality Management \& Business Excellence , 87-99.

Ojasalo J. (2006). Quality for the individual and for the company in the business to business market. International Journal of Quality \& Reliability Management, 62-78.

Prakash A, Jha SK, Prasad KD, Singh AK. (2017). Productivity, quality and business performance: an empirical study. International Journal of Productivity and Performance Management , 78-91.

Rina Tresnawati,Evi Octavia, Shinta Dewi Herawati. (2017). The Effect of Efficiency and Quality Cost on Probability. Review of Integrative Business and Economics Research , 296-304.

Sailaja A, P C Basak and K G Viswanadhan. (2015). HIDDEN COSTS OF QUALITY: MEASURUMENT\& ANALIYSIS. International Journal of Managing Value and Supply Chains , 13-25.

Taylor, BW III \& Russell R.S. (2000). Operatiotions management multimedia version. upper Saddle River, NJ: Prentice Hall.

Tolentino A.L. (2004 ( 13-14 may)). New concepts of productivity and its improvement. presented at european Productivity Networ kSeminar (hal. 1-7). Europa: Budapest.

Vincent K. Omachonu, Sakesun Suthummanon, Norman G. Einspruch. (2004). The relationship between quality and quality cost for a manufacturing company".. International Journal of Quality \& Reliability Management, 277-290.

Yu Lin, Biwei Liang, Xuechang Zhu,. (2018). The effect of inventory performance on product quality: The mediating effect of financial performance. International Journal of Quality \& Reliability Management . 